\title{
Melanoma of the Uvea Pathologic Primary Tumor TNM Finding v7
}

National Cancer Institute

\section{Source}

National Cancer Institute. Melanoma of the Uvea Pathologic Primary Tumor TNM

Finding v7. NCl Thesaurus. Code C88668.

A pathologic finding about one or more characteristics of melanoma of the uvea,

following the rules of the TNM AJCC V7 classification system as they pertain to staging of the primary tumor. 